Article

\title{
Assessment of Soil Redistribution Following Land Rehabilitation with an Apple Orchard in Hilly Regions of Central Iran
}

\author{
Shamsollah Ayoubi ${ }^{1}$ (D), Ameneh Mohammadi ${ }^{1}$, Mohammad Reza Abdi ${ }^{2}$, Farideh Abbaszadeh Afshar ${ }^{3}$, \\ Lin Wang $4,5, *$ (D) and Mojtaba Zeraatpisheh ${ }^{4,5, *(D)}$
}

Citation: Ayoubi, S.; Mohammadi, A.; Abdi, M.R.; Abbaszadeh Afshar, F.;

Wang, L.; Zeraatpisheh, M.

Assessment of Soil Redistribution Following Land Rehabilitation with an Apple Orchard in Hilly Regions of Central Iran. Agronomy 2022, 12, 451. https://doi.org/10.3390/ agronomy12020451

Academic Editors: Bořivoj Šarapatka, Miroslav Dumbrovský

and Jana Podhrázská

Received: 30 December 2021

Accepted: 8 February 2022

Published: 11 February 2022

Publisher's Note: MDPI stays neutral with regard to jurisdictional claims in published maps and institutional affiliations.

Copyright: (C) 2022 by the authors. Licensee MDPI, Basel, Switzerland. This article is an open access article distributed under the terms and conditions of the Creative Commons Attribution (CC BY) license (https:// creativecommons.org/licenses/by/ $4.0 /)$.
1 Department of Soil Science, College of Agriculture, Isfahan University of Technology, Isfahan 84156-83111, Iran; ayoubi@iut.ac.ir (S.A.); ameneh.mohammadi@yahoo.com (A.M.)

2 Department of Physics, Faculty of Science, University of Isfahan, Isfahan 81747-73441, Iran; r.abdi@phys.ui.ac.ir

3 Department of Soil Science, College of Agriculture, University of Jiroft, Jiroft 78671-61167, Iran; f.abbaszadeh@ujiroft.ac.ir

4 College of Geography and Environmental Science, Henan University, Kaifeng 475004, China

5 Henan Key Laboratory of Earth System Observation and Modeling, Henan University, Kaifeng 475004, China

* Correspondence: wanglin@henu.edu.cn (L.W.); mojtaba.zeraatpisheh@henu.edu.cn (M.Z.)

Abstract: This study was executed to explore soil redistribution and soil quality changes induced by land degradation and then rehabilitation by orchard plantation in different slope positions in a semi-arid region in central Iran. A total of 72 surface soil samples $(0-30 \mathrm{~cm})$ were collected from three land uses (natural rangelands, dryland farming, and apple orchards) in four slope positions (shoulder, backslope, footslope, and toeslope). The soil physicochemical properties and magnetic parameters were measured, and soil redistribution was determined in the selected soil samples using the ${ }^{137} \mathrm{Cs}$ technique. The results showed that rangeland degradation and, subsequently, rainfed cultivation, led to a significant decline in the soil quality indicators, such as soil organic matter (SOM), total nitrogen $(\mathrm{TN})$, available potassium ( $\left.\mathrm{K}_{\mathrm{ava}}\right)$, and available phosphorous $\left(\mathrm{P}_{\mathrm{ava}}\right)$, thus incurring further soil loss, as determined by the ${ }^{137} \mathrm{C}$ s technique. Conversely, the conversion and rehabilitation of drylands to apple orchards cultivated on the contour terraces improved soil quality significantly and decreased soil loss $(p<0.05)$ and soil quality grade $(p<0.01)$. Additionally, the findings indicated that slope positions relative to land use change had a reasonable impact on the variability of soil properties and soil loss and deposition. The results of ${ }^{137} \mathrm{Cs}$ analysis showed that the drylands had the highest soil loss (185.3 $\left.\mathrm{t} \mathrm{ha}^{-1} \mathrm{yr}^{-1}\right)$ and maximum sedimentation (182. $\left.5 \mathrm{tha}^{-1} \mathrm{yr}^{-1}\right)$ in the shoulder and footslope positions, respectively. The random forest model applied between ${ }^{137} \mathrm{Cs}$ inventory and soil properties indicated that calcium carbonate equivalent (CCE), TN, $\mathrm{P}_{\mathrm{ava}}, \mathrm{K}_{\mathrm{ava}}$, and bulk density ( $\rho b)$ could explain $75 \%$ of the total variability in ${ }^{137} \mathrm{Cs}$ inventory with high $\mathrm{R}^{2}(0.94)$ and low RMSE (111.29). Magnetic measurements have shown great potential as a cost-effective and fast method for assessing soil redistribution in hilly regions, as confirmed by the findings of the ${ }^{137} \mathrm{Cs}$ analysis, which agreed well with the magnetic susceptibility at low frequency $\left(\chi_{l f}\right)$. Overall, the results confirmed that restoring abandoned dryland by orchard cultivation may improve soil quality and diminish soil loss in the semi-arid region of Iran. However, further research is required to assess other aspects of the ecosystem affected by this restoration.

Keywords: soil rehabilitation; ${ }^{137}$ Cs technique; magnetic susceptibility; random forest; soil quality index

\section{Introduction}

Population expansion and increasing demand for land resources have placed significant pressure on ecosystems, such as natural rangelands, due to overgrazing in pursuit of more fresh meals. As a consequence, inappropriate cultivation practices such as plowing 
along the slope gradient accelerate soil erosion, increase flood risk, and cause natural capital losses [1]. Rangeland degradation significantly reduces soil quality and incurs further soil loss. Several studies confirmed that overgrazing reduces soil quality indicators, including soil organic matter [2-4], soil nutrients [3,5], soil porosity [6], soil infiltration [6], and biomass production [5]. However, it increases bulk density [2,5], runoff, and soil loss [7,8].

Soil erosion is a natural incident that affects all landforms, especially undulating landscapes and hilly regions $[9,10]$, which could impose enormous pressures on natural and agricultural ecosystems [11]. Slope steepness has a vital role in the degree of degradation or restoration of soil properties following rangeland degradation and soil erosion [2]. The hillslope positions have contributed significantly to the soil detachment variability at the landscape scale [12]. Therefore, knowledge about soil redistribution in the landscape is crucial for landowners and decision makers to choose the most proper management practices [13].

Numerous approaches have been developed to evaluate the quantity of soil loss or deposition at the landscape scale. The most important approaches for estimating soil loss/deposition are classified into various categories: direct measures, physical-based models, empirical models, conceptual models/hybrid models [14-16], and isotopic radionuclide models [17-19]. Isotopic techniques based on the use of fallout radionuclides such as Caesium-137 ( ${ }^{137} \mathrm{Cs}$ ) have already been used successfully to estimate soil loss and deposition, especially over a mid-term period [18,20-22]. Zapata [23] and Lacoste et al. [24] showed that the ${ }^{137} \mathrm{Cs}$ can be a helpful approach to use tracing soil redistribution and erosion in different regions. Moreover, the ${ }^{137} \mathrm{Cs}$ inventory demonstrated a high correlation with soil properties and field measurement $[12,24]$. However, since the radionuclide method is costly and labor-consuming, new methods, such as magnetic susceptibility, have attracted the attention of researchers $[9,25,26]$.

In recent decades, a significant portion of natural rangelands in central Iran, including the southern Isfahan province, has suffered from overgrazing and undergone dryland farming [2,27]. Changes of natural rangeland to dryland farming have led to several threats, such as severe soil erosion, calamitous floods accompanied by destructive consequences, and a decrease in the region's biodiversity. In some degraded areas and drylands, rehabilitation by apple orchards is being applied as an alternative land use. Some investigations have been conducted to determine the effects of rehabilitation of degraded lands on improving the ecosystem quality [28-31]. For instance, studying the rehabilitation of the degraded pasture in Minas Gerais, Brazil, by a secondary forest, Schiavon Lopes et al. [6] showed that the afforestation of the degraded land led to higher soil-water infiltration, larger macroporosity, and greater carbon storage compared to the pasture areas. To assess the impacts of land use conversion on soil quality indicators, soil quality indices (SQIs) are a widely used and simple method of quantifying soil quality [32-34]. The SQI assessment may help increase our knowledge of soil ecosystems and enable more effective management.

So far, few investigations have been conducted on the effects of the rehabilitation by orchards in arid and semi-arid regions. Knowledge about the effects of the land use change, especially orchard cultivation, on soil quality and soil redistribution in steep slopes is required for more efficient land use management. Therefore, the major objectives of this study were to (i) explore the effects of the land use change and the orchard cultivation on some soil quality parameters and magnetic properties in different slope positions, (ii) evaluate soil redistribution following the land use change using the ${ }^{137} \mathrm{Cs}$ technique, and (iii) examine relationships between soil quality properties and quantity of soil redistribution and erosion measured by ${ }^{137} \mathrm{Cs}$ in the semi-arid region in the south of Isfahan province, central Iran.

\section{Materials and Methods}

\subsection{Description of the Study Area}

The study area is located in central Iran in the southern part of Isfahan province, between $31^{\circ} 25^{\prime}$ and $31^{\circ} 26^{\prime} \mathrm{N}$ latitudes, and between $51^{\circ} 34^{\prime}$ and $51^{\circ} 35^{\prime} \mathrm{E}$ longitudes (Figure 1). 
The average elevation of the studied site is $2400 \mathrm{~m}$ a.s.l. The mean annual precipitation and the mean annual temperature are $400 \mathrm{~mm}$ and $15.6^{\circ} \mathrm{C}$, respectively. The soil moisture and temperature regimes of the study area are Xeric and Mesic, respectively. Moreover, soils are classified as Typic Calcixerepts and Typic Xerorthents, according to Soil Survey Staff [35]. The studied hills have similar parent materials, including dissected, quaternary alluvial deposits for three land uses (i.e., natural rangeland, dryland farming, and apple orchards). Specifically, the major geological formation units in the study area consist of limestone, dolomite, marl, conglomerate, and silt- and sand- stone (Figure 1c).

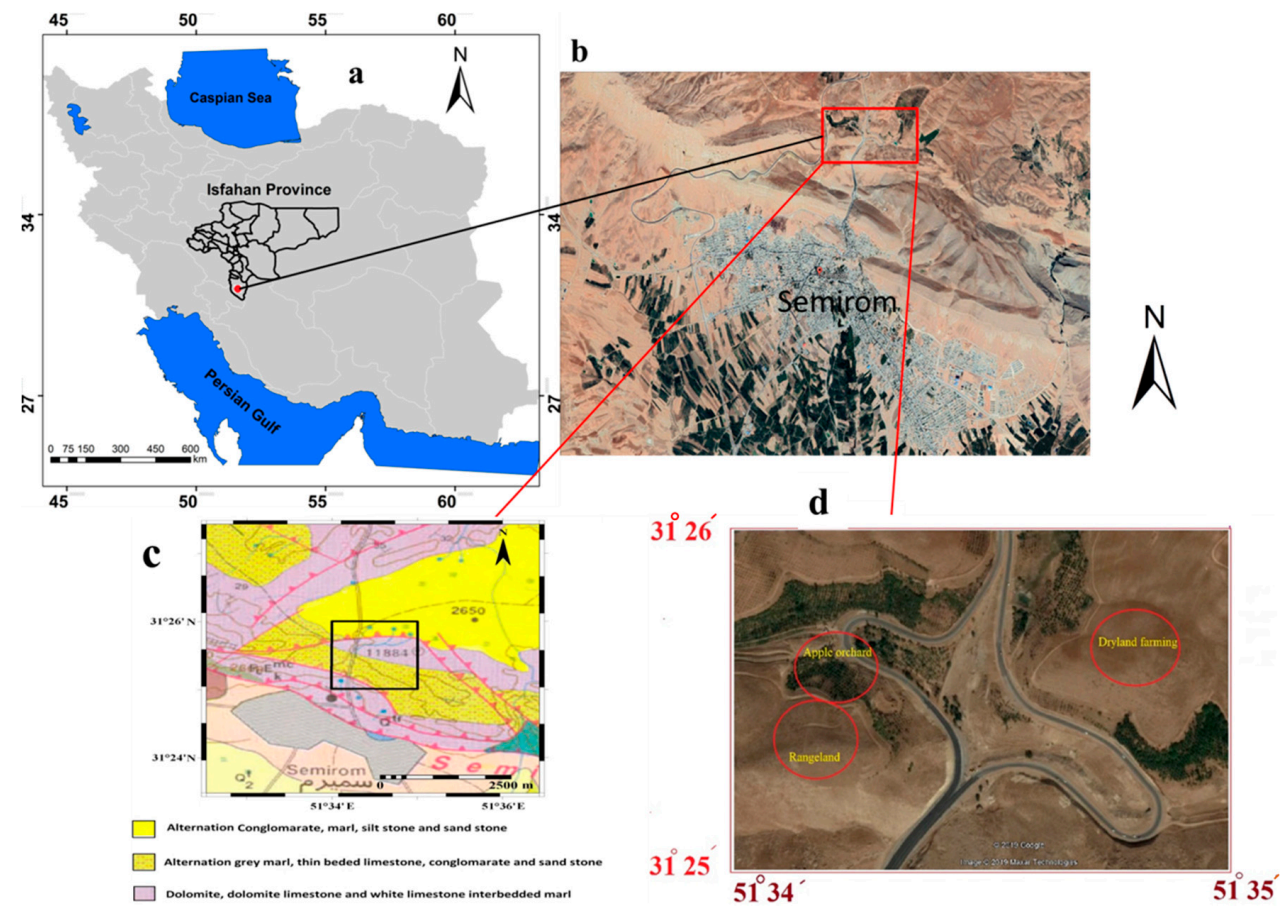

Figure 1. Location of the study area. (a) Isfahan province among all the provinces in Iran, (b) location of the study area in the Semirom district, (c) geology map and the geological formations in the region, and (d) location of three land uses in the study area.

In the study area, the erosive evidence, including rill, sheet erosions, and the appearance of lime spots (carbonate calcium parent materials) in some places on the surface has been observed. As the study areas are a local site and cannot be illustrated by satellite images with high resolutions (for example, Landsat imagery $30 \mathrm{~m} \times 30 \mathrm{~m}$ ), there is no historical satellite imagery in the region. Thus, based on the personal correspondence with local residents and farmers, the rangelands were converted to dryland farming 50 years ago, and the apple orchard cultivation has reclaimed the abandoned drylands (or lowincome drylands) in the last 20 years. Native vegetation in the rangelands predominantly comprises Astragalus verus, Bromus tomentellus, Elymus gentry, Cousinia cylindracea, and Daphne mucronata. Dryland farming is predominantly undertaken for barley and wheat production. Apple orchards (Malus pumila) are grown on the contour terraces (Banquet) upon application of traditional manure and administration of cultivation practices.

\subsection{Soil Sampling}

At three hillslopes corresponding to three land uses, four slope positions, namely shoulder, backslope, footslope, and toeslope, were identified (Figure 1c). The selected hillslopes were located at the southern aspect (see Figure 1), with similar slope gradients around 15-20\%. Six soil samples were randomly collected from each slope position at a $0-30 \mathrm{~cm}$ depth. In order to demonstrate the soil sample distribution on the map, a three-dimensional representation of the sampling method is shown in Figure 2 as a typical 
three-dimensional pattern. In total, 24 soil samples were collected from each land use. Thus, a total of 72 soil samples were sampled across the studied hillslopes. For the evaluation of soil loss/deposition using ${ }^{137} \mathrm{Cs}$, a reference site was selected on flat slopes near the sites where the undisturbed rangelands were located, and the soil samples were collected from the depth intervals of $0-5,5-10,10-15,15-20,20-25$, and $25-30 \mathrm{~cm}$ in the $20 \mathrm{~m} \times 20 \mathrm{~m}$ area. All soil samples were air-dried, passed through a $2 \mathrm{~mm}$ sieve, and prepared for laboratory analyses.

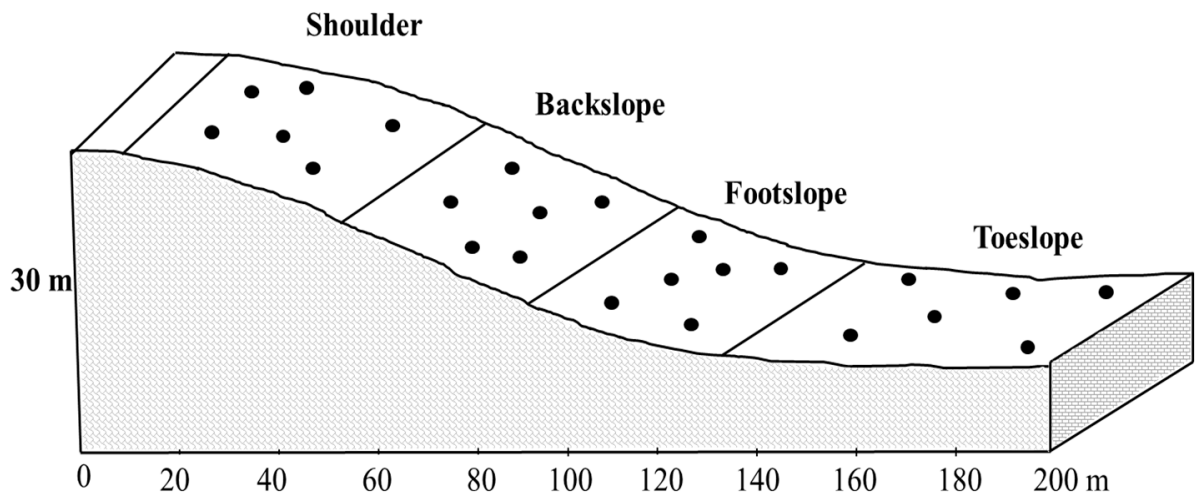

Figure 2. Three-dimensional pattern of sampling scheme in the study area in different hillslope positions.

\subsection{Laboratory Analyses}

Particle size distribution, soil bulk density $(\rho b)$, soil organic matter (SOM) content, and calcium carbonate equivalent (CCE) were determined by the Bouyoucos hydrometer method [36], the core method, the Walkley and Black method [37], and Bernard's calcimetric method [38], respectively. Electrical conductivity (EC) and $\mathrm{pH}$ were measured in the soil/water extract ratio of 1:2.5. Total nitrogen (TN) was measured by the Kjeldahl method [39]. Available phosphorus $\left(\mathrm{P}_{\mathrm{ava}}\right)$ and available potassium $\left(\mathrm{K}_{\mathrm{ava}}\right)$ were measured by the methods proposed by Carter and Gregorich [40]. For magnetic measurements, after crushing, the Bartington MS2 dual-frequency sensor was used to measure soil magnetic susceptibility $(\chi)$ at low $\left(0.47 \mathrm{kHz} ; \chi_{\mathrm{lf}}\right)$ and high frequencies $\left(4.7 \mathrm{kHz}, \chi_{\mathrm{hf}}\right)$ in all samples using approximately $20 \mathrm{~g}$ of soil held in a clear plastic vial (2.3 cm in diameter) [41]. The dependent frequency $\left(\chi_{\mathrm{fd}}\right)$ was calculated using the following equation:

$$
\chi_{\mathrm{fd}}=\frac{\left(\chi_{\mathrm{lf}}-\chi_{\mathrm{hf}}\right)}{\chi_{\mathrm{lf}}} \times 100
$$

The ${ }^{137} \mathrm{Cs}$ inventory was measured in the samples after preparation. Accordingly, $500 \mathrm{~g}$ of the dried and sieved soils were placed in the Marinelli beakers and sealed for ${ }^{137} \mathrm{Cs}$ analyses. Gamma spectroscopy with a high-resolution germanium detector was used to measure the ${ }^{137} \mathrm{Cs}$ activity $\left(\mathrm{Bq} \mathrm{kg}^{-1}\right)$ from the net area of a full-energy peak at $662 \mathrm{keV}$ (ISO, 11929-1, 2000) in the Department of Physics, Isfahan University of Iran, during 2018-2019. The quality of the measurements was monitored using a reference material, no: IAEA-375, from the International Atomic Energy Agency (IAEA). The count time was nearly $150 \mathrm{~min}$, and the counting error was preserved at the level of $10 \%$ and $95 \%$ confidence. The ${ }^{137} \mathrm{Cs}$ activities $\left(\mathrm{Bq} \mathrm{kg}^{-1}\right)$ were turned to the area activities $\left(\mathrm{Bq} \mathrm{m}^{-2}\right)$.

\subsection{Soil Redistribution Assessment}

Soil redistribution rate ( $\mathrm{t} \mathrm{ha}^{-1} \mathrm{yr}^{-1}$ ) was assessed by the ${ }^{137} \mathrm{Cs}$ inventory at any location and compared with the reference site using the simplified mass balance model (SMBM) [42]. According to the SMBM, Equation (2) could be used for the eroded locations:

$$
Y=10 \rho b \times d / P\left(1-\frac{X}{100}\right)^{\frac{1}{t-1963}}
$$




$$
X=\frac{137_{\text {Csreference site }}-137_{\text {Csgiven point }}}{137_{\text {Csreference site }}} \times 100
$$

where $Y=$ mean annual soil loss $\left(t \mathrm{ha}^{-1} \mathrm{yr}^{-1}\right), \rho b=$ bulk density $\left(\mathrm{kg} \mathrm{m}^{-3}\right), d=$ depth of plow or cultivation layer $(\mathrm{m}), X=$ percent of loss or excess of ${ }^{137} \mathrm{C}$ s inventory, and $P=$ correction factor for particle size distribution.

The rate of soil deposition at the depositional sites $\left(\mathrm{R}^{\prime}\right)$, where the ${ }^{137} \mathrm{C}$ s inventory is higher than the reference site, was calculated by the following equation:

$$
\mathrm{R}^{\prime}=\frac{A_{e x}(t)}{\int_{1963}^{t} C_{d}\left(t^{\prime}\right) e^{-\lambda\left(t-t^{\prime}\right)} d t^{\prime}}=\frac{A(t)-A_{r e f}}{\int_{1963}^{t} C_{d}\left(t^{\prime}\right) e^{-\lambda\left(t-t^{\prime}\right)} d t^{\prime}}
$$

where $A_{e x}(t)$ is the extra ${ }^{137} \mathrm{Cs}$ inventory in the sampling over the reference inventory in the year $t^{\prime}$ (defined as the inventory determined to be lower than the local reference inventory based on $\left.\mathrm{Bq} \mathrm{m}^{-2}\right), \mathrm{Cd}(t)$ is the ${ }^{137} \mathrm{C}$ s concentration of the deposited sediment in the year $t^{\prime}$ based on $\mathrm{Bq} \mathrm{kg}^{-1}$, and $\lambda$ is the constant of ${ }^{137} \mathrm{C}$ s decay $\left(\mathrm{yr}^{-1}\right)$.

\subsection{Soil Quality Index (SQI) Assessment}

In this study, several soil properties (i.e., EC, $\mathrm{pH}, \mathrm{CCE}, \mathrm{SOM}, \mathrm{TN}, \mathrm{P}_{\mathrm{ava}}, \mathrm{K}_{\mathrm{ava}}$, and $\rho \mathrm{b}$ ) were considered as indicators of SQI assessment. The selected soil properties define soil health, productivity, fertility, soil degradation, and soil and water interaction.

The linear scoring method was used to transform soil properties into a dimensionless score (between 0.1 and 1) using the following functions: 'more is better' for soil properties including SOM, TN, $\mathrm{P}_{\mathrm{ava}}, \mathrm{K}_{\mathrm{ava}}$; ' 'less is better' for $\mathrm{CCE}, \rho b$, and optimal range for $\mathrm{pH}$ and EC $[33,34]$ (Table S1). The optimal values $0.2-2 \mathrm{dS} \mathrm{m}^{-1}$ and 7 were used for $\mathrm{EC}$ and $\mathrm{pH}$, respectively [32].

The Nemoro SQI $\left(\mathrm{SQI}_{n}\right)$ equation $[30,31]$ is defined as the following equation:

$$
\mathrm{SQI}_{\mathrm{n}}=\sqrt{\frac{\mathrm{P}_{\mathrm{ave}}{ }^{2}+\mathrm{P}_{\min }{ }^{2}}{2}} \times \frac{\mathrm{n}-1}{\mathrm{n}}
$$

where $\mathrm{P}_{\mathrm{ave}}, \mathrm{P}_{\min }$, and $\mathrm{n}$ are the average value, the minimum value for the scores attained for each sampling point, and the number of indicators, respectively. The SQI was divided into five categories, namely, very high (I), high (II), moderate (III), low (IV), and very low (V).

\subsection{Statistical Analysis and Modeling}

Descriptive statistics, including minimum, maximum, standard deviation, coefficient of variation $(\mathrm{CV})$, and skewness, were determined by SPSS v. 19.0 (SPSS Inc. Chicago, IL, USA). The correlations between the studied variables were also computed using SPSS 19.0 [43]. A linear and non-linear relationship between ${ }^{137} \mathrm{Cs}$ and magnetic susceptibility $\left(\chi_{\mathrm{lf}}\right)$ was constructed to understand better the relationship between $\chi_{\mathrm{lf}}$ and the rate of soil loss/deposition. Additionally, a random forest model was used to predict the ${ }^{137} \mathrm{Cs}$ inventory as the dependent variable, with magnetic susceptibility and soil physicochemical properties as independent variables. Two user-defined parameters in the random forest model, namely, the number of trees in the forest (ntree) and the number of environmental covariates in each random subset (mtry), were optimized based on the out-of-bag error [44]. The importance of the independent variables in the random forest was calculated based on the variable importance [45]. The ${ }^{137} \mathrm{Cs}$ inventory modeling performance was evaluated using ten-fold cross-validation with ten repetitions by the coefficient of determination $\left(\mathrm{R}^{2}\right)$, mean absolute error (MAE), and the root mean square error (RMSE). The random forest model was conducted in the R3.3.1 program using the 'caret' package [46].

A random block design was applied for the statistical analysis, and the data were examined using analysis of variance (ANOVA). The mean comparison was performed using the LSD method at the probability level of $p<0.05$. All graphs were plotted in the Excel program (v. 2013). 


\section{Results and Discussion}

\subsection{Descriptive Statistics}

The results of the descriptive analysis for the studied properties, including soil physicochemical properties, magnetic susceptibility, and ${ }^{137} \mathrm{C}$ s inventory, are presented in Table 1. According to the results of the Kolmogorov-Smirnoff test, all studied variables were normally distributed in three land uses (Table 1). The skewness values presented in Table 1 also confirmed the normal distribution of the variables (varied from -1.11 to +1.10 ). The coefficient of variation (CV) was used as the criterion to define the variability in the studied soil parameters in each land use. The results showed that, among the soil variables, TN values showed the highest CV values of 39.67, 64.10, and 38.14\% for the rangelands, drylands, and apple orchards, respectively.

\subsection{Soil Loss and Deposition Rates}

The ${ }^{137}$ CS technique was used to assess soil loss and soil deposition (soil redistribution) in this study. The content of ${ }^{137} \mathrm{Cs}$ significantly differed among the land uses in four slope positions (Figure 5). The figure shows that the lowest and highest values for ${ }^{137} \mathrm{Cs}$ were observed in dryland farming land use's shoulder and toeslope positions (Figure 5a). The inventory of ${ }^{137} \mathrm{Cs}$ in the reference site, near the selected sites, was $2552 \mathrm{~Bq} \mathrm{~m}^{-2}$. In western Iran, in the landscapes with comparable elevation, climate, and latitude, Afshar et al. [20] and Ayoubi et al. [47] reported ${ }^{137} \mathrm{Cs}$ equal to 2107 and $2130 \mathrm{~Bq} \mathrm{~m}^{-2}$ for the reference sites. By applying ${ }^{137} \mathrm{Cs}$ in the reference site and the ${ }^{137} \mathrm{Cs}$ loss in each location, soil loss/deposition was calculated using Equations (2) and (4). The soil loss/deposition results for three land uses in different slope positions are given in Figure $5 \mathrm{~b}$. The net soil loss occurred in the following order in the shoulder position: dryland $>$ apple orchard $>$ rangeland. The highest soil loss $\left(185.3 \mathrm{t} \mathrm{ha}^{-1} \mathrm{yr}^{-1}\right)$ in the shoulder position of dryland indicated the effects of tillage by the local farmers, especially in the direction of the slope gradient. Similarly, Rahimi et al. [21] demonstrated soil loss of $110 \mathrm{t} \mathrm{ha}^{-1} \mathrm{yr}^{-1}$ in the shoulder position after pasture degradation and intensive cultivation in the Fereydunshahr district in western Iran. Applying the simplified mass balance model (SMBM), Theocharopoulos et al. [78] reported the highest value for soil loss of $168.19 \mathrm{t} \mathrm{ha}^{-1} \mathrm{yr}^{-1}$ in the steep slope of the cultivated area in central Greece.

Similarly, Karchengani et al. [58] and Khormali et al. [48] reported higher CCE content after deforestation and clear-cutting of forests in Lordegan district, west of Iran, and northern Iran, respectively. The highest value of CCE content was observed in the apple orchards. Although lower CCE was expected in the orchards due to lower soil erosion, higher CCE in this land use might be attributed to deep tillage for tree cultivation (Figure 3a).

Figure $3 \mathrm{~b}$ shows the variability of soil phosphorus $\left(\mathrm{P}_{\mathrm{ava}}\right)$ in surface soils in three land uses and four slope positions. The highest $\mathrm{P}_{\text {ava }}$ values were observed in the apple orchards, which may be attributed to reducing soil loss and more fertilization by farmers. Moreover, the highest content was observed in the toeslope position, which was presumably ascribed to the transformation of phosphorus accompanied by the fine particles transported from higher to lower positions by runoff. The lowest phosphorous in the drylands confirmed the process of soil erosion and the depletion of the soil surface from the soil nutrients. Similar results were obtained for values of $\mathrm{K}_{\mathrm{ava}}$ (Figure $3 \mathrm{c}$ ) and TN (Figure 3d). Several studies confirmed that the reclamation of bare lands significantly affected the status of soil nutrients [31,59], which could be related to various factors, such as the rate of fertilization, the kinds of applied fertilizers, the modes of plant configuration, the tillage practices, and the kind of land use after reclamation in particular $[31,60,61]$. Additionally, the reclamation age is another important factor regulating soil nutrients [31]. In our study area, the reclamation by the orchards in contour terraces (Banquet), accompanied by relatively high fertilization employed by NPK fertilizers, made a significant contribution to the total amounts of nitrogen, phosphorous, and potassium (Figure 3). 
Table 1. Descriptive statistics of studied variables in three selected land uses.

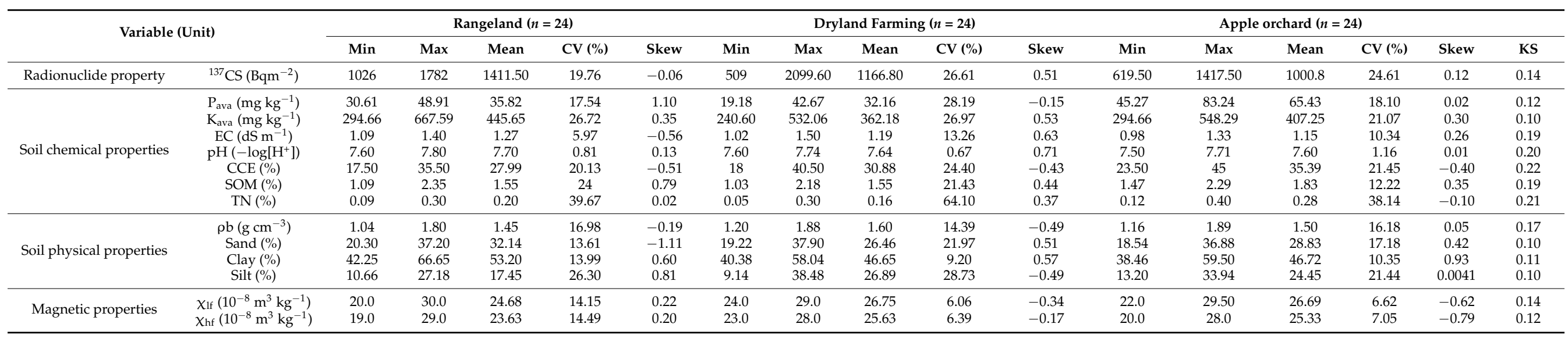

${ }^{137}$ Cs: Caesium inventory; $\mathrm{P}_{\text {ava }}$ : available phosphorous; $\mathrm{K}_{\mathrm{ava}}$ : available potassium; EC: Electrical conductivity; CCE: Calcium carbonate equivalent; TN: Total nitrogen; $\rho$ b: bulk density; $\chi_{\mathrm{lf}}$ : magnetic susceptibility at low frequency; $\chi_{\mathrm{hf}}$ : magnetic susceptibility at high frequency; Skew: Skewness. KS: Kolmogorov-Smirnoff criteria. 

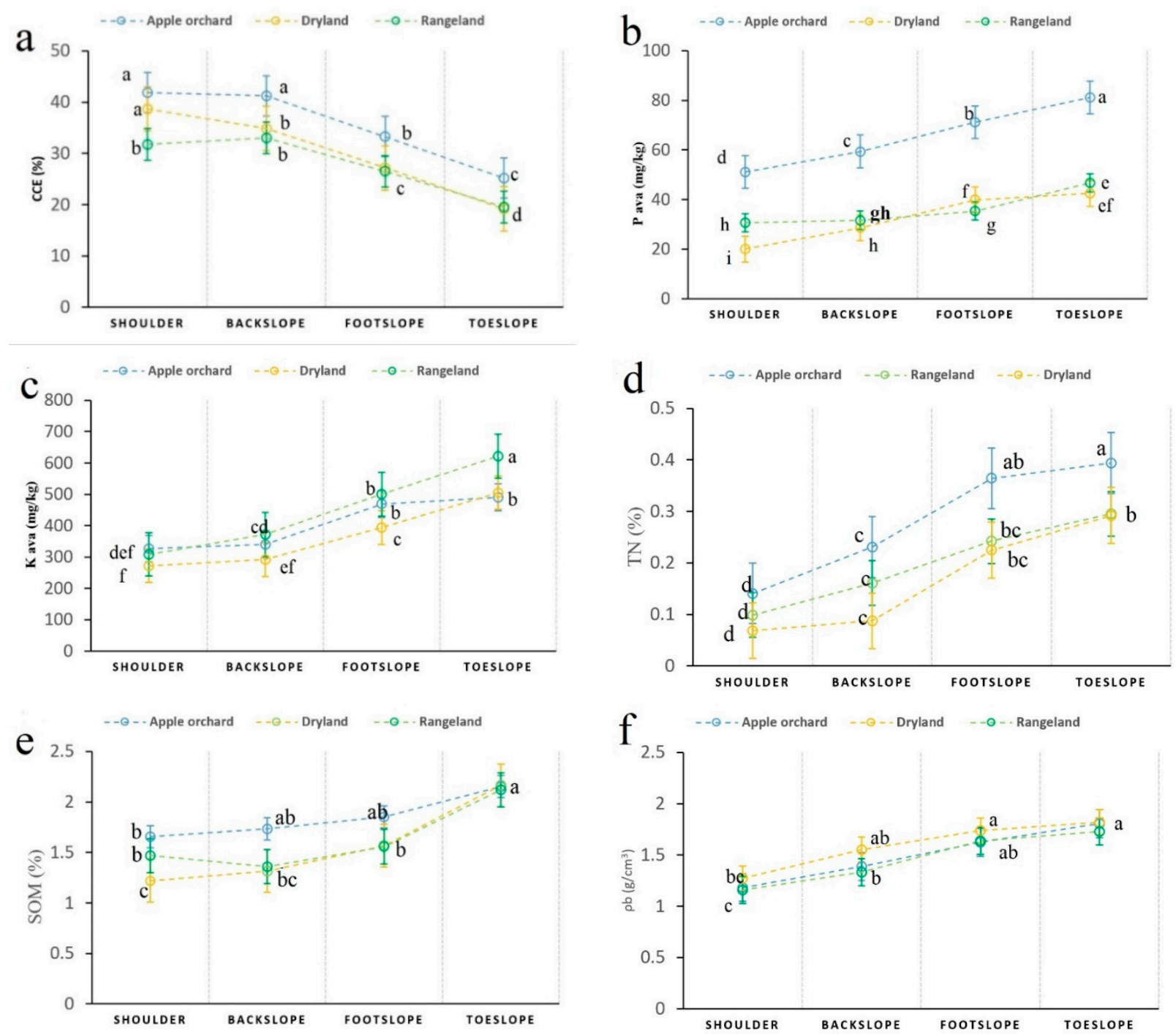

Figure 3. Variability of some soil properties at a 0-30 $\mathrm{cm}$ depth in various land uses at four slope positions in the study area: (a) CCE (calcium carbonate equivalent), TN: total nitrogen; (b) $\mathrm{P}_{\text {ava }}$ (available phosphorus); (c) $\mathrm{K}_{\mathrm{ava}}$ (available phosphorus), (d) TN (total nitrogen); (e) SOM (soil organic matter); (f) $\rho b$ (bulk density). Means $(n=24)$ with the same letter are significantly different using the least significant difference (LSD) test at $p<0.01$.

The variability in SOM contents for the various land uses in four different slope positions is given in Figure 3e. The mean values for SOM among the land uses were 1.83, 1.55, and $1.55 \%$ for the apple orchards, rangelands, and dryland farming, respectively (Table 1 , Figure 3). Both pasture degradation and conversion to dryland farming [62] decreased SOM contents (Figure 3). Following the change in the land use from the rangelands to the cultivated lands, the SOM values decreased to $20.4,3.02,3.05$, and $2.01 \%$ in the shoulder, backslope, footslope, and toeslope positions, respectively (Figure 3). Ayoubi et al. [2], Li et al. [63], and Mohammed et al. [64] reported a decrease in the SOM values following grassland conversion to cultivated lands in the rangelands of western Iran and the pastures of Mongolia, respectively. Several studies indicated that cultivation can significantly reduce the SOC pools by breaking large aggregates into smaller aggregates and exposing SOM to oxidation processes and microbial decomposition [34,65-68].

The restoration of drylands by orchards increased SOM, particularly in the shoulder, backslope, and footslope positions (Figure 3e). The orchards' rehabilitation of degraded soils increased SOM values even higher than those of initial rangelands, which may be 
due to the slow decomposition rate of orchard wood litters than grasslands and the nearby farmers' manure application (Figure 3e). Several scholars reported an increase in the SOM pools after recovering the degraded lands because of the decomposition of plants (especially perennials), animal bodies, and microorganisms [28,31]. Following the trend in SOM variability from shoulder to toeslope positions, the SOM values were the lowest and the highest in the shoulder and toeslope positions, respectively, in all land uses. Several investigations on the variability of SOM values in different slope positions indicated that the highest SOM values in the lower slope positions were due to soil redistribution and massive transportation of materials along the hillslopes [48,58].

The variations of bulk density $(\rho b)$ along the slope position in three land uses are given in Figure 3f. As Figure $3 \mathrm{f}$ shows, the land use conversion significantly influenced the bulk density. The highest $\rho b$ was observed in the drylands cultivated with the soils having a high rate of plowing and lower SOM values, which was consistent with the findings of other studies $[65,69]$.

The comparison of the means and SQI assessment in different land uses and slope positions are shown in Tables 2 and 3, respectively. The results indicate that the mean values of SQIs among different land uses and slope positions showed significant differences $(p<0.01)$ (Table 3). Among different land uses, we found the highest and lowest SQIs in the apple orchard and dryland farming land uses, respectively (Table 3), which can directly be due to the higher values of SOM, $\mathrm{P}_{\mathrm{ava}}$, and TN (Figure 3). Apple orchard land use showed a high soil quality grade, whereas dryland farming and rangeland land uses had a moderate soil quality grade (Tables 2 and 3). Numerous research has shown that land use modification significantly affects soil qualities [2,27,33,34,48,67]. Moreover, the highest SQIs were found in the toeslope positions among different land uses (Table 3). In the rehabilitation of the degraded soils with apple orchards in footslope and toeslope positions, the SQIs showed a very high soil quality grade, mainly due to receiving the soil depositions with a high amount of SOM, $\mathrm{P}_{\mathrm{ava}}, \mathrm{K}_{\mathrm{ava}}$, and $\mathrm{TN}$ as positive soil indicators and less of the negative soil indicator (CCE) in the SQI assessment (Table 3 and Figure 3).

Table 2. Soil quality grade classification for indices and indicator methods.

\begin{tabular}{cccccccc}
\hline \multirow{2}{*}{ Index } & \multirow{2}{*}{$\begin{array}{l}\text { Indicator } \\
\text { Method }\end{array}$} & \multirow{2}{*}{ SSF } & \multicolumn{4}{c}{ Soil Quality Grades } \\
\cline { 4 - 9 } & TDS & Linear & I (Very High) & II (High) & III (Moderate) & IV (Low) & V (Very Low) \\
\hline SQI $_{n}$ & & & $>0.459$ & $0.400-0.459$ & $0.341-0.400$ & $0.281-0.341$ & $<0.281$ \\
\hline
\end{tabular}

\subsection{Variability in Magnetic Susceptibility}

Figure $4 \mathrm{a}$ indicates the changes in magnetic susceptibility among the land uses in different slope positions. The lowest magnetic susceptibility was observed in the shoulder position in apple orchards, whereas the highest was found on the toeslope in apple orchards and dryland farming (Figure 4a). Several mechanisms have been suggested for enhancing the magnetic susceptibility of surface soils. The major sources include soil pedogenesis [70], inherited from the parent material [2], industrial and urbanization activities [71], and biogeochemical processes induced by petroleum hydrocarbon pollution [72,73]. As this study was carried out far away from pollution sources and all parent materials were limestones with low magnetic susceptibility, any increase in $\chi_{\text {lf }}$ was related to the pedogenic processes [74]. Furthermore, the high positive significant relationship between $\chi_{\mathrm{fd}}$ and $\chi_{\mathrm{lf}}$ $(r=0.70, p<0.01$; Figure $4 \mathrm{~b})$ confirmed that the magnetic susceptibility was increased by the pedogenic processes, including an increase in the super-paramagnetic particles and neoformation minerals (e.g., illite and chlorite clay minerals and goethite) [75]. Followed by the pedogenic formation of ferrimagnetic minerals, their distribution along the landscape was highly dependent on soil redistribution and mechanical processes. The higher $\chi_{1 f}$ in the lower position was related to soil deposition, and the lower $\chi_{l f}$ in the upper position was related to soil loss (Figure 4a). During soil erosion processes, the fine materials associated with magnetic minerals were transferred from upper positions (i.e., shoulder) to lower 
positions (i.e., toeslope) $[25,58,76]$. Lower magnetic susceptibility in the shoulder position of the apple orchards compared to drylands was unusual (Figure 4a), despite having lower soil loss in the apple orchards. It seems that lower magnetic susceptibility in the apple orchards in the shoulder position may be related to higher CCE as a diamagnetic mineral reducing magnetic susceptibility due to less soil erosion (Figures 3a and 4a) [77].

\subsection{Soil Loss and Deposition Rates}

The ${ }^{137} \mathrm{CS}$ technique was used to assess soil loss and soil deposition (soil redistribution) in this study. The content of ${ }^{137}$ Cs significantly differed among the land uses in four slope positions (Figure 5). The figure shows that the lowest and highest values for ${ }^{137} \mathrm{Cs}$ were observed in dryland farming land use's shoulder and toeslope positions (Figure 5a). The inventory of ${ }^{137} \mathrm{Cs}$ in the reference site, near the selected sites, was $2552 \mathrm{~Bq} \mathrm{~m}{ }^{-2}$. In western Iran, in the landscapes with comparable elevation, climate, and latitude, Afshar et al. [20] and Ayoubi et al. [47] reported ${ }^{137} \mathrm{Cs}$ equal to 2107 and $2130 \mathrm{~Bq} \mathrm{~m}^{-2}$ for the reference sites. By applying ${ }^{137} \mathrm{Cs}$ in the reference site and the ${ }^{137} \mathrm{Cs}$ loss in each location, soil loss/deposition was calculated using Equations (2) and (4). The soil loss/deposition results for three land uses in different slope positions are given in Figure 5b. The net soil loss occurred in the following order in the shoulder position: dryland > apple orchard $>$ rangeland. The highest soil loss $\left(185.3 \mathrm{tha}^{-1} \mathrm{yr}^{-1}\right)$ in the shoulder position of dryland indicated the effects of tillage by the local farmers, especially in the direction of the slope gradient. Similarly, Rahimi et al. [21] demonstrated soil loss of $110 \mathrm{tha}^{-1} \mathrm{yr}^{-1}$ in the shoulder position after pasture degradation and intensive cultivation in the Fereydunshahr district in western Iran. Applying the simplified mass balance model (SMBM), Theocharopoulos et al. [78] reported the highest value for soil loss of $168.19 \mathrm{t} \mathrm{ha}^{-1} \mathrm{yr}^{-1}$ in the steep slope of the cultivated area in central Greece. 
Table 3. Comparison of the mean values of soil quality indices in different land uses and slope positions.

\begin{tabular}{|c|c|c|c|c|c|c|c|c|c|c|c|c|c|}
\hline \multicolumn{2}{|c|}{ Land Use } & \multicolumn{3}{|c|}{ Rangeland $(n=24)$} & \multicolumn{4}{|c|}{ Dryland Farming $(n=24)$} & \multicolumn{4}{|c|}{ Apple Orchard $(n=24)$} & \multirow{3}{*}{$\begin{array}{c}\operatorname{Pr}>\mathbf{F} \\
0.0002 *\end{array}$} \\
\hline & & & & & & & & & & & & & \\
\hline \multirow[t]{2}{*}{$\mathrm{SQI}_{\mathrm{n}}$} & Shoulder & backslope & footslope & toeslope & Shoulder & backslope & footslope & toeslope & Shoulder & backslope & footslope & toeslope & \\
\hline & $0.306^{c}$ & $0.326^{c}$ & $0.399^{b}$ & $0.458^{a}$ & $0.267^{c}$ & $0.276^{c}$ & $0.369^{b}$ & $0.432^{\mathrm{a}}$ & $0.345^{b}$ & $0.372^{b}$ & $0.499^{a}$ & $0.498^{\mathrm{a}}$ & 0.0001 * \\
\hline
\end{tabular}

* Significant at the 0.01 . Means $(n=24)$ with the same letter are significantly different using the least significant difference (LSD) test at $p<0.01$. SQI : Nemoro soil quality index. 
$\boldsymbol{a}$

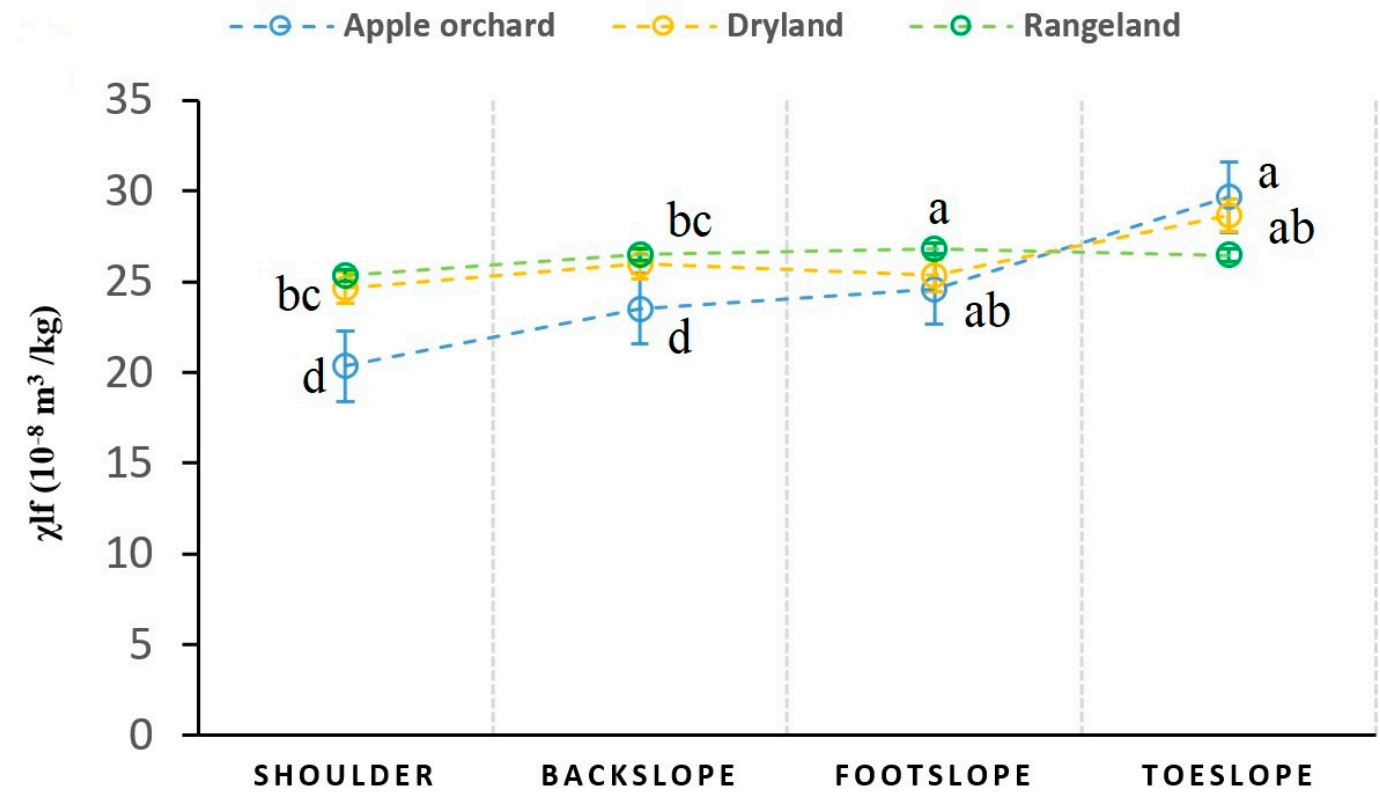

b

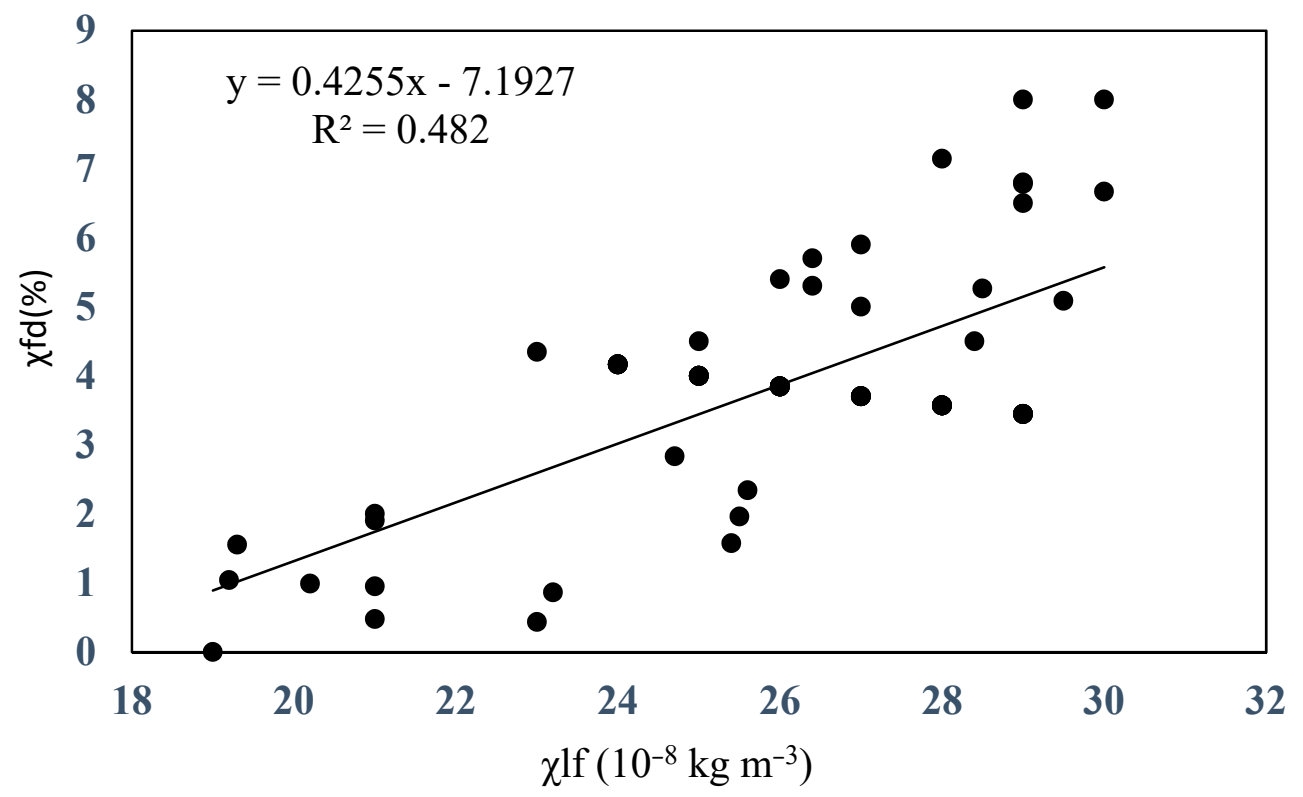

Figure 4. Variability in magnetic susceptibility $\left(\chi_{\mathrm{lf}}\right)$ at three land uses in four slope positions $(\mathbf{a}, \mathbf{b})$ the relationship between $\chi_{\mathrm{lf}}$ and $\chi_{\mathrm{fd}}$ for all studied soil samples. Means with the same letter are significantly different using the least significant difference (LSD) test at $p<0.01$. 


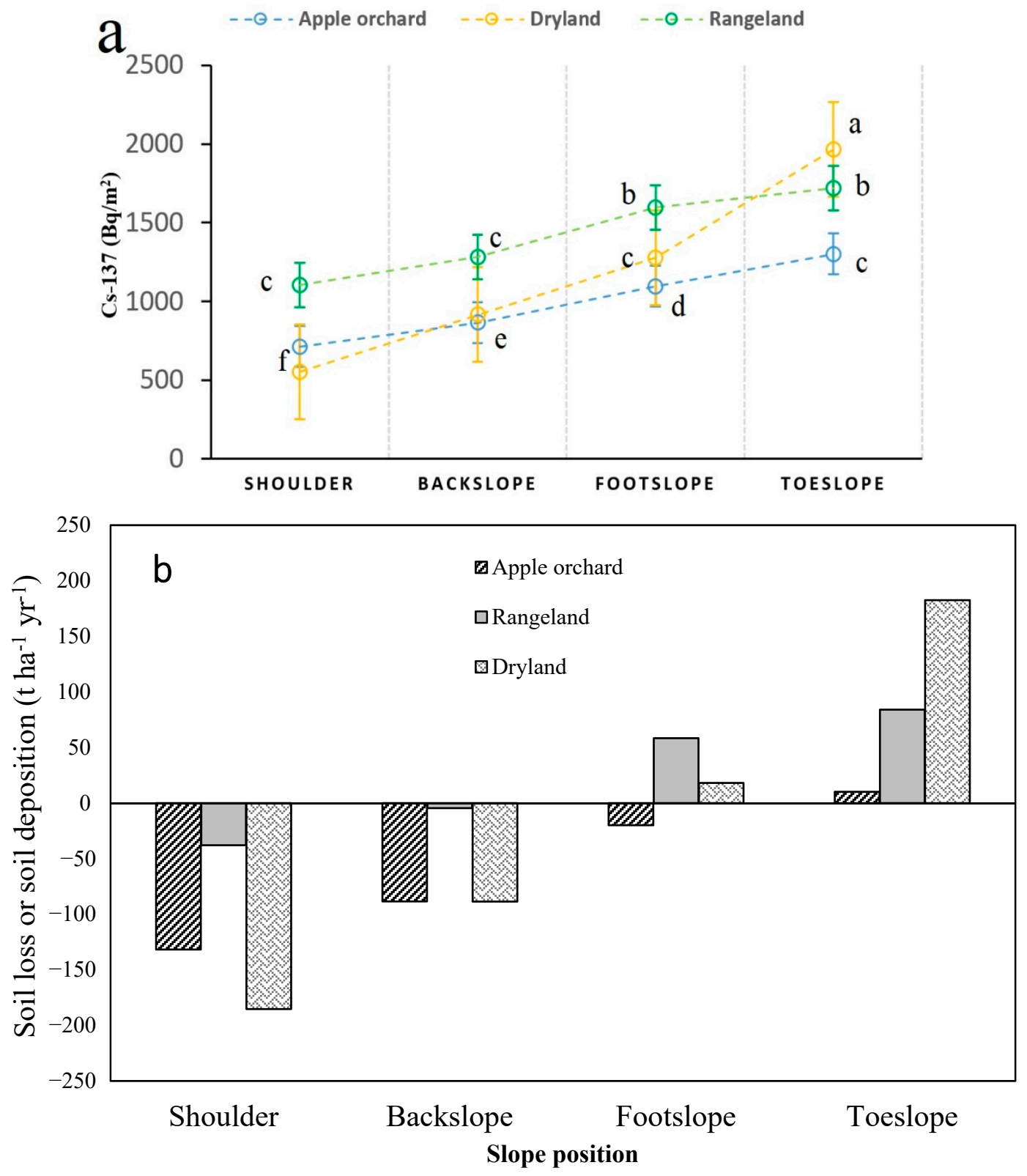

Figure 5. Variability in magnetic susceptibility $\left(\chi_{\mathrm{lf}}\right)$ at three land uses in four slope positions, means with the same letter are significantly different using the least significant difference (LSD) test at $p<0.01(\mathbf{a}, \mathbf{b})$ the relationship between $\chi_{\mathrm{lf}}$ and $\chi_{\mathrm{fd}}$ for all studied soil samples.

\subsection{Correlation Analysis and Modeling}

The results of the correlation analysis among the studied variables, as the indicators of soil redistribution along the hillslopes, are presented in Table 4 . According to the results, ${ }^{137} \mathrm{Cs}$ was significantly correlated with $\mathrm{SOM}(0.87, p<0.01), \mathrm{K}_{\mathrm{ava}}(0.85, p<0.01)$, TN $(0.95$, $p<0.05), \mathrm{P}_{\mathrm{ava}}(0.89, p<0.01), \mathrm{\rho b}(0.99, p<0.05), \mathrm{\chi}_{\mathrm{lf}}(0.47, p<0.01)$, and $\mathrm{\chi}_{\mathrm{hf}}(0.52, p<0.05)$ (Table 4). 
Table 4. Correlation coefficients among the soil properties in the studied sites at different land uses.

\begin{tabular}{|c|c|c|c|c|c|c|c|c|}
\hline Variable & ${ }^{137} \mathrm{CS}$ & SOM & $\mathbf{K}_{\text {ava }}$ & CCE & TN & $\rho b$ & $\mathbf{P}_{\mathrm{ava}}$ & $\chi_{1 f}$ \\
\hline \multicolumn{9}{|c|}{ Apple orchard $(n=24)$} \\
\hline${ }^{137} \mathrm{CS}$ & 1 & & & & & & & \\
\hline SOM & $0.87 * *$ & 1 & & & & & & \\
\hline $\mathrm{K}_{\mathrm{ava}}$ & $0.85^{* *}$ & $0.66^{* *}$ & 1 & & & & & \\
\hline CCE & $-0.95^{* *}$ & $-0.87^{* *}$ & $-0.74^{* *}$ & 1 & & & & \\
\hline $\mathrm{TN}$ & $0.95^{* *}$ & $0.77^{* *}$ & $-0.83^{* *}$ & $-0.87^{* *}$ & 1 & & & \\
\hline$\rho b$ & $0.99 * *$ & $0.86^{* *}$ & $0.91^{* *}$ & $-0.93^{* *}$ & $0.95^{* *}$ & 1 & & \\
\hline $\mathrm{P}_{\text {ava }}$ & $0.89 * *$ & $0.84^{* *}$ & $0.84^{* *}$ & $-0.94^{* *}$ & $0.94 * *$ & $0.98^{* *}$ & 1 & * \\
\hline$\chi_{\mathrm{lf}}$ & $0.42 * *$ & 0.26 & $0.84^{* *}$ & $-0.41 *$ & $0.53^{* *}$ & $0.47^{* *}$ & $0.55^{* *}$ & 1 \\
\hline \multicolumn{9}{|c|}{ Dryland farming $(n=24)$} \\
\hline${ }^{137} \mathrm{CS}$ & 1 & & & & & & & \\
\hline $\mathrm{SOM}$ & $0.83^{* *}$ & 1 & & & & & & \\
\hline $\mathrm{K}_{\mathrm{ava}}$ & $0.96^{* *}$ & $0.89 * *$ & 1 & & & & & \\
\hline CCE & $-0.98^{* *}$ & $-0.85^{* *}$ & $-0.97^{* *}$ & 1 & & & & \\
\hline $\mathrm{TN}$ & $0.91^{* *}$ & $0.79 * *$ & $0.93^{* *}$ & $-0.93^{* *}$ & 1 & & & \\
\hline$\rho b$ & $0.90 * *$ & $0.64^{* *}$ & $0.83 * *$ & $-0.90^{* *}$ & $0.83 * *$ & 1 & & \\
\hline $\mathrm{P}_{\mathrm{ava}}$ & $0.93^{* *}$ & $0.71 * *$ & $0.90 * *$ & $-0.94 * *$ & $0.93 * *$ & $0.97^{* *}$ & 1 & \\
\hline$\chi_{\mathrm{lf}}$ & $0.47^{*}$ & 0.39 & $0.44^{*}$ & $-0.45^{*}$ & 0.27 & -0.43 * & 0.33 & 1 \\
\hline \multicolumn{9}{|c|}{ Rangeland $(n=24)$} \\
\hline${ }^{137} \mathrm{CS}$ & 1 & & & & & & & \\
\hline $\mathrm{SOM}$ & $0.80^{* *}$ & 1 & & & & & & \\
\hline $\mathrm{K}_{\mathrm{ava}}$ & $0.94^{* *}$ & $0.90^{* *}$ & 1 & & & & & \\
\hline CCE & $-0.84^{* *}$ & $-0.87^{* *}$ & $-0.92^{* *}$ & 1 & & & & \\
\hline $\mathrm{TN}$ & $0.96^{* *}$ & $0.82 * *$ & $0.96^{* *}$ & $-0.85^{* *}$ & 1 & & & \\
\hline$\rho b$ & $0.99 * *$ & $0.78^{* *}$ & $0.93^{* *}$ & $-0.83^{* *}$ & $0.96^{* *}$ & 1 & & \\
\hline $\mathrm{P}_{\mathrm{ava}}$ & $0.82 * *$ & $0.84^{* *}$ & $0.88^{* *}$ & $-0.92^{* *}$ & $0.84^{* *}$ & $0.81^{* *}$ & 1 & \\
\hline$\chi_{\mathrm{lf}}$ & $0.42 *$ & 0.3 & 0.34 & 0.37 & 0.35 & 0.38 & $0.44^{*}$ & 1 \\
\hline
\end{tabular}

$* * *$, Significant at 95 and $99 \%$ probability level. ${ }^{137}$ Cs: Caesium inventory; SOM: Soil organic matter; $\mathrm{K}_{\text {ava }}$ : available potassium; $\mathrm{P}_{\text {ava }}$ : available phosphorous; $\mathrm{CCE}$ : calcium carbonate equivalent; TN: total nitrogen; $\rho$ b: bulk density; $\chi_{\mathrm{If}}$ : magnetic susceptibility at low frequency; $\chi_{\mathrm{hf}}$ : magnetic susceptibility at high frequency.

The variability in the soil nutrients $\left(\mathrm{K}_{\mathrm{ava}}, \mathrm{P}_{\mathrm{ava}}\right.$, and $\left.\mathrm{TN}\right)$ was highly related to SOM, as shown in Table 4. The high and positive correlations found between SOM and these nutrients confirmed their connection. In the shoulder position with a high rate of soil erosion and lower ${ }^{137} \mathrm{Cs}$ (Figure 5), SOM was associated with nutrients detached and transported to the lower position (Figure 3e). Studying the forest soils in Germany, Fujiyoshi and Sawamura [82] reported a significant relationship between potassium and ${ }^{137}$ Cs inventory $(r=0.90)$. The positive and significant relationship observed between ${ }^{137} \mathrm{Cs}$ and $\rho b$ confirmed that intensive cultivation practices were followed in the lower position, leading to the accumulation of more materials and ${ }^{137} \mathrm{Cs}$. Moreover, ${ }^{137} \mathrm{Cs}$ inventory showed a negative correlation with CCE, indicating that a lower inventory of ${ }^{137} \mathrm{Cs}$ was excited in the steep slopes with the high content of CCE (Table 4). Overall, significant relationships between ${ }^{137} \mathrm{C}$ s inventory and soil properties confirmed that erosional and hydrological processes can regulate soil variability in the hilly regions of the study area [18]. These findings were consistent with the results of Karchegnai et al. [18,21,47,80,83].

Relatively high and positive correlations were obtained between magnetic measures $\left(\chi_{\mathrm{lf}}\right)$ and ${ }^{137} \mathrm{Cs}$ inventories in three land uses (Table 4). Magnetic susceptibility was previously utilized as a soil redistribution tracer [47]. Ferrimagnetic minerals, such as maghemite and magnetite, are associated with fine materials (i.e., clay particles); they have translocated from upper slopes to lower slopes through soil redistribution, leading to an increase in soil magnetic susceptibility in lower positions $[9,21,76,84]$. The non-linear relationship between ${ }^{137} \mathrm{Cs}$ and $\chi_{\mathrm{lf}}$ was studied to understand better the relationship between $\chi_{\mathrm{lf}}$ and the rate of soil loss/deposition. The results of this analysis for three land uses are shown in 
Figure 6. As can be seen, non-linear correlations between ${ }^{137} \mathrm{Cs}$ and magnetic susceptibility were significantly higher than linear correlations. Similarly, in the Fereydunshahr district, Rahimi et al. [21] showed that non-linear relationships could explain $74 \%$ and $76 \%$ of the variability in ${ }^{137} \mathrm{Cs}$ in the pasture and cultivated soils, respectively. In Chelgerd district, Charmahal and Bakhtiari province, west of Iran, Ayoubi et al. [47] found $R^{2}=0.45$ for the non-linear relationships between ${ }^{137} \mathrm{Cs}$ and magnetic susceptibility.
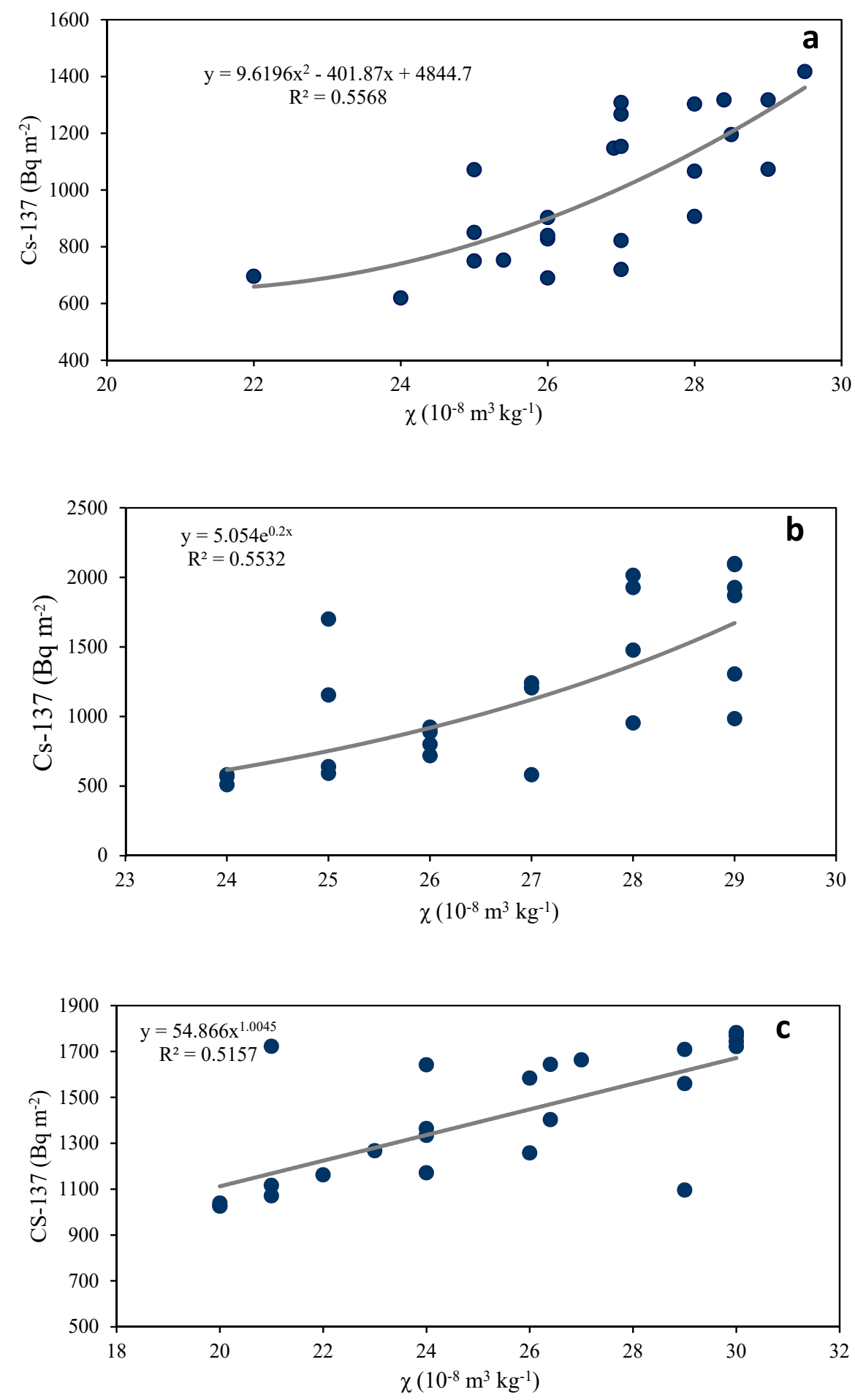

Figure 6. Non-linear relationships between $\chi_{\text {lf }}$ and ${ }^{137}$ Cs inventory in three land uses: (a) apple orchard; (b) dryland; (c) rangeland. 
The ${ }^{137} \mathrm{Cs}$ inventory content was predicted using the random forest and soil properties to explore the contribution of the studied soil properties to explaining the variability in ${ }^{137} \mathrm{Cs}$ in the study area. The validation criteria and variable importance for predicting ${ }^{137} \mathrm{Cs}$ inventory by random forest model are shown in Table 5 and Figure 7 , respectively. The best prediction accuracy ( $\mathrm{RMSE}=111.29$ and $\mathrm{R}^{2}=0.46$ ) for predicting ${ }^{137} \mathrm{C}$ inventory was achieved for the number of environmental covariates in each random subset (mtry = 13) and the number of trees in the forest (ntree = 500) (Table 5). Previous studies confirmed that the random forest model is a robust machine learning approach for predicting soil properties [45,85-87]. The variable importance analysis showed that soil properties, including CCE, TN, available phosphorous $\left(\mathrm{P}_{\mathrm{ava}}\right)$, available potassium $\left(\mathrm{K}_{\mathrm{ava}}\right)$, and $\rho \mathrm{b}$, were the most important variables in random forest prediction, which, in total, can explain $75 \%$ of the variability in ${ }^{137} \mathrm{Cs}$ in the study area (Figure 7). Thus, this result confirmed the effects of erosional processes on the soil properties along the hillslopes. In the Chelgerd district of Iran, Ayoubi et al. [47] showed that soil properties such as $\mathrm{K}_{\mathrm{ava}}$ and $\chi_{\mathrm{lf}}$ were identified as the most important variables, explaining $61 \%$ of the variability in ${ }^{137} \mathrm{C}$ s inventory.

Table 5. Random forest model results between ${ }^{137} \mathrm{CS}$ inventory as the dependent variable and soil properties as independent variables in the study area.

\begin{tabular}{cccccc}
\hline Variable & mtry & ntree & RMSE \pm SD & $\mathbf{R}^{2} \pm$ SD & MAE \pm SD \\
\hline${ }^{137}$ CS inventory & 13 & 500 & $111.29 \pm 26.85$ & $0.94 \pm 0.04$ & $89.58 \pm 23.75$
\end{tabular}

mtry: number of variables in each random subset; ntree: number of trees in the forest; RMSE: root mean square error; $\mathrm{R}^{2}$ : coefficient of determination; MAE: mean absolute error.

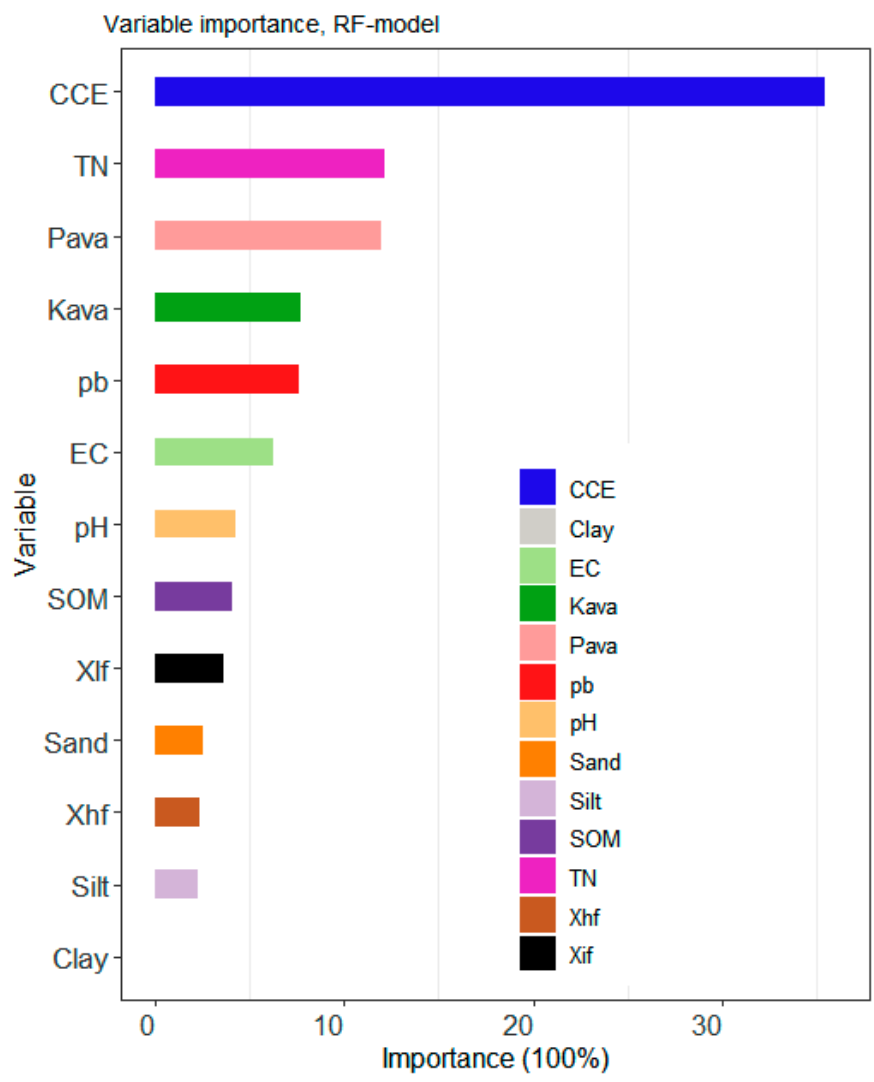

Figure 7. The variable importance analysis of soil properties in the prediction of ${ }^{137} \mathrm{Cs}$ inventory for the random forest model. CCE: calcium carbonate equivalent; TN: total nitrogen; $\mathrm{P}_{\mathrm{ava}}$ : available phosphorous; $\mathrm{K}_{\mathrm{ava}}$ : available potassium; $\rho$ : bulk density; EC: electrical conductivity; SOM: soil organic matter; $\chi_{\mathrm{lf}}$ : magnetic susceptibility at low frequency; $\chi_{\mathrm{hf}}$ : magnetic susceptibility at high frequency. 


\section{Conclusions}

This study investigated the effects of land use changes (especially rehabilitation with an apple orchard) and slope positions on the variability of soil physicochemical and magnetic properties, and soil redistribution using the ${ }^{137} \mathrm{C}$ s technique in three land uses. The main conclusions are:

1. Two factors, namely rangeland degradation and land conversion to dryland farming, have significantly changed the soil physicochemical properties in various slope positions during the past 50 years. CCE increased in the eroded positions (shoulder and backslope), whereas SOM, TN, $\mathrm{K}_{\mathrm{ava}}$, and $\mathrm{P}_{\mathrm{ava}}$ decreased in these positions, especially in dryland farming, because of soil loss. The rehabilitation of the degraded soils with apple orchards significantly improved soil quality indicators.

2. The restoration of drylands by orchards improved SQIs in different slope positions. The apple orchards increased SQI values in footslope (0.499, very high) and toeslope (0.498, very high) positions compared to drylands $(0.369$, moderate for footslope; 0.432 , high for toeslope).

3. Magnetic susceptibility is significantly reduced in dryland farming compared to rangeland due to soil erosion and deposition along the landscape. In the upper position, lower values for $\chi_{\text {lf }}$ were observed, whereas the highest $\chi_{\text {lf }}$ were found in the lower position due to the movement of magnetic particles associated with fine particles.

4. Applying SMBM on the ${ }^{137}$ Cs inventory indicated the highest soil loss observed in the dryland and orchard cultivation regions. Thus, it can be concluded that land rehabilitation significantly decreased the soil loss rate in the recent two decades. In the steep slopes (i.e., shoulder and backslope) and the lower positions (i.e., footslope and toeslope) of three land uses, net soil loss and net deposition occurred, respectively.

5. The correlation analysis showed that ${ }^{137} \mathrm{Cs}$ well correlated with some soil properties known to be soil quality indicators (i.e., $\mathrm{TN}, \mathrm{K}_{\mathrm{ava}}, \mathrm{P}_{\mathrm{ava}}, \mathrm{SOM}$, bulk density, and CCE). The good agreement between ${ }^{137} \mathrm{C}$ s inventory and $\chi_{\text {lf }}$ confirmed the high potential of magnetic susceptibility, as an indicator, for evaluating soil redistribution along the hillslope. Additionally, the random forest models revealed that CCE, TN, $\mathrm{K}_{\mathrm{ava}}, \mathrm{P}_{\mathrm{ava}}$, and $\rho b$ were the most important variables, explaining $75 \%$ of the variability of ${ }^{137} \mathrm{Cs}$ inventory in the study area.

Supplementary Materials: The following supporting information can be downloaded at: https: / www. mdpi.com/article/10.3390/agronomy12020451/s1, Table S1: Standard scoring functions and indicators parameters in the study area (SSF Equations were adopted from Zeraatpisheh et al. [34]).

Author Contributions: Conceptualization, S.A., A.M. and M.Z.; methodology, S.A., A.M. and M.Z.; software, S.A., A.M. and M.Z.; validation, S.A., A.M. and M.Z.; formal analysis, S.A., A.M. and M.Z.; investigation, S.A., and A.M.; resources, S.A., A.M. and M.R.A.; data curation, S.A., A.M. and M.R.A.; writing—original draft preparation, S.A., A.M., F.A.A. and M.Z.; writing-review and editing, S.A., A.M., F.A.A., L.W. and M.Z.; visualization S.A. and M.Z.; supervision, S.A.; project administration, S.A.; funding acquisition, S.A. All authors have read and agreed to the published version of the manuscript.

Funding: This research was financially supported by Isfahan University of Technology.

Data Availability Statement: Not applicable.

Acknowledgments: The authors thank the Isfahan University of Technology for providing the experimental facilities. Mojtaba Zeraatpisheh's postdoctoral program at Henan University, China, has been supported by the National Key Research and Development Program of China, grant numbers 2017YFA0604302 and 2018YFA0606500.

Conflicts of Interest: The authors declare no conflict of interest. 


\section{References}

1. Rodrigo Comino, J.; Iserloh, T.; Morvan, X.; Malam Issa, O.; Naisse, C.; Keesstra, S.D.; Cerdà, A.; Prosdocimi, M.; Arnáez, J.; Lasanta, T.; et al. Soil erosion processes in European vineyards: A qualitative comparison of rainfall simulation measurements in Germany, Spain and France. Hydrology 2016, 3, 6. [CrossRef]

2. Ayoubi, S.; Emami, N.; Ghaffari, N.; Honarjoo, N.; Sahrawat, K.L. Pasture degradation effects on soil quality indicators at different hillslope positions in a semiarid region of western Iran. Environ. Earth Sci. 2014, 71, 375-381. [CrossRef]

3. Kooch, Y.; Moghimian, N.; Wirth, S.; Noghre, N. Effects of grazing management on leaf litter decomposition and soil microbial activities in northern Iranian rangeland. Geoderma 2020, 361, 114100. [CrossRef]

4. Zeraatpisheh, M.; Bottega, E.L.; Bakhshandeh, E.; Owliaie, H.R.; Taghizadeh-Mehrjardi, R.; Kerry, R.; Scholten, T.; Xu, M. Spatial variability of soil quality within management zones: Homogeneity and purity of delineated zones. Catena 2022, $209,105835$. [CrossRef]

5. Müller, M.M.; Guimaraes, M.F.; Desjardins, T.; Mitja, D. The relationship between pasture degradation and soil properties in the Brazilian Amazon: A case study. Agric. Ecosyst. Environ. 2004, 103, 279-288. [CrossRef]

6. Lopes, V.S.; Cardoso, I.M.; Fernandes, O.R.; Rocha, G.C.; Simas, F.N.B.; de Melo Moura, W.; Santana, F.C.; Veloso, G.V.; da Luz, J.M.R. The establishment of a secondary forest in a degraded pasture to improve hydraulic properties of the soil. Soil Tillage Res. 2020, 198, 104538. [CrossRef]

7. Vaezi, A.R.; Zarrinabadi, E.; Auerswald, K. Interaction of land use, slope gradient and rain sequence on runoff and soil loss from weakly aggregated semi-arid soils. Soil Tillage Res. 2017, 172, 22-31. [CrossRef]

8. Hosseinalizadeh, M.; Alinejad, M.; Behbahani, A.M.; Khormali, F.; Kariminejad, N.; Pourghasemi, H.R. A review on the gully erosion and land degradation in Iran. In Gully Erosion Studies from India and Surrounding Regions; Springer: Cham, Switzerland, 2020; pp. 393-403.

9. Bouhlassa, S.; Bouhsane, N. Assessment of areal water and tillage erosion using magnetic susceptibility: The approach and its application in Moroccan watershed. Environ. Sci. Pollut. Res. 2019, 26, 25452-25466. [CrossRef]

10. Mohammed, S.; Abdo, H.G.; Szabo, S.; Pham, Q.B.; Holb, I.J.; Linh, N.T.T.; Anh, D.T.; Alsafadi, K.; Mokhtar, A.; Kbibo, I.; et al. Estimating human impacts on soil erosion considering different hillslope inclinations and land uses in the coastal region of Syria. Water 2020, 12, 2786. [CrossRef]

11. Mohammed, S.; Alsafadi, K.; Talukdar, S.; Kiwan, S.; Hennawi, S.; Alshihabi, O.; Sharaf, M.; Harsanyie, E. Estimation of soil erosion risk in southern part of Syria by using RUSLE integrating geo informatics approach. Remote Sens. Appl. Soc. Environ. 2020, 20, 100375. [CrossRef]

12. Cerdà, A.; Rodrigo-Comino, J. Is the hillslope position relevant for runoff and soil loss activation under high rainfall conditions in vineyards? Ecohydrol. Hydrobiol. 2020, 20, 59-72. [CrossRef]

13. Liu, H.; Zhang, T.; Liu, B.; Liu, G.; Wilson, G. Effects of gully erosion and gully filling on soil depth and crop production in the black soil region, northeast China. Environ. Earth Sci. 2013, 68, 1723-1732. [CrossRef]

14. Renard, K.G.; Foster, G.; Yoder, D.; McCool, D. RUSLE revisited: Status, questions, answers, and the future. J. Soil Water Conserv. 1994, 49, 213-220.

15. Taghizadeh-Mehrjardi, R.; Bawa, A.; Kumar, S.; Zeraatpisheh, M.; Amirian-Chakan, A.; Akbarzadeh, A. Soil erosion spatial prediction using digital soil mapping and RUSLE methods for Big Sioux River watershed. Soil Syst. 2019, 3, 43. [CrossRef]

16. Safwan, M.; Alaa, K.; Omran, A.; Quoc, B.P.; Nguyen, T.T.L.; Van, N.T.; Duong, T.A.; Endre, H. Predicting soil erosion hazard in Lattakia Governorate (W Syria). Int. J. Sediment Res. 2021, 36, 207-220. [CrossRef]

17. Quijano, L.; Gaspar, L.; Navas, A. Spatial patterns of SOC, SON, 137Cs and soil properties as affected by redistribution processes in a Mediterranean cultivated field (Central Ebro Basin). Soil Tillage Res. 2016, 155, 318-328. [CrossRef]

18. La Manna, L.; Gaspar, L.; Tarabini, M.; Quijano, L.; Navas, A. 137Cs inventories along a climatic gradient in volcanic soils of Patagonia: Potential use for assessing medium term erosion processes. Catena 2019, 181, 104089. [CrossRef]

19. Junge, B.; Mabit, L.; Dercon, G.; Walling, D.E.; Abaidoo, R.; Chikoye, D.; Stahr, K. First use of the 137 Cs technique in Nigeria for estimating medium-term soil redistribution rates on cultivated farmland. Soil Tillage Res. 2010, 110, 211-220. [CrossRef]

20. Afshar, F.A.; Ayoubi, S.; Jalalian, A. Soil redistribution rate and its relationship with soil organic carbon and total nitrogen using 137Cs technique in a cultivated complex hillslope in western Iran. J. Environ. Radioact. 2010, 101, 606-614. [CrossRef]

21. Rahimi, M.R.; Ayoubi, S.; Abdi, M.R. Magnetic susceptibility and Cs-137 inventory variability as influenced by land use change and slope positions in a hilly, semiarid region of west-central Iran. J. Appl. Geophys. 2013, 89, 68-75. [CrossRef]

22. Ayoubi, S.; Sadeghi, N.; Afshar, F.A.; Abdi, M.R.; Zeraatpisheh, M.; Rodrigo-Comino, J. Impacts of oak deforestation and rainfed cultivation on soil redistribution processes across hillslopes using 137 Cs techniques. For. Ecosyst. 2021, 8, 32. [CrossRef]

23. Zapata, F. Field Application of the Cs-137 Technique in Soil Erosion and Sedimentation. Special Issue. Soil Tillage Res. 2003, 69, 153. [CrossRef]

24. Lacoste, M.; Michot, D.; Viaud, V.; Evrard, O.; Walter, C. Combining 137Cs measurements and a spatially distributed erosion model to assess soil redistribution in a hedgerow landscape in northwestern France (1960-2010). Catena 2014, 119, 78-89. [CrossRef]

25. Sadiki, A.; Faleh, A.; Navas, A.; Bouhlassa, S. Using magnetic susceptibility to assess soil degradation in the Eastern Rif, Morocco. Earth Surf. Processes Landf. 2009, 34, 2057-2069. [CrossRef] 
26. Menshov, O.; Kruglov, O.; Vyzhva, S.; Nazarok, P.; Pereira, P.; Pastushenko, T. Magnetic methods in tracing soil erosion, Kharkov Region, Ukraine. Studia Geophys. Geod. 2018, 62, 681-696. [CrossRef]

27. Nael, M.; Khademi, H.; Hajabbasi, M. Response of soil quality indicators and their spatial variability to land degradation in central Iran. Appl. Soil Ecol. 2004, 27, 221-232. [CrossRef]

28. Józefowska, A.; Pietrzykowski, M.; Woś, B.; Cajthaml, T.; Frouz, J. The effects of tree species and substrate on carbon sequestration and chemical and biological properties in reforested post-mining soils. Geoderma 2017, 292, 9-16. [CrossRef]

29. Wang, J.; Yang, R.; Feng, Y. Spatial variability of reconstructed soil properties and the optimization of sampling number for reclaimed land monitoring in an opencast coal mine. Arab. J. Geosci. 2017, 10, 46. [CrossRef]

30. Wang, J.; Hu, X.; Shi, T.; He, L.; Hu, W.; Wu, G. Assessing toxic metal chromium in the soil in coal mining areas via proximal sensing: Prerequisites for land rehabilitation and sustainable development. Geoderma 2022, 405, 115399. [CrossRef]

31. Guan, Y.; Zhou, W.; Bai, Z.; Cao, Y.; Huang, Y.; Huang, H. Soil nutrient variations among different land use types after reclamation in the Pingshuo opencast coal mine on the Loess Plateau, China. Catena 2020, 188, 104427. [CrossRef]

32. Andrews, S.; Flora, C.; Mitchell, J.; Karlen, D. Growers' perceptions and acceptance of soil quality indices. Geoderma 2003, 114, 187-213. [CrossRef]

33. Nabiollahi, K.; Golmohamadi, F.; Taghizadeh-Mehrjardi, R.; Kerry, R.; Davari, M. Assessing the effects of slope gradient and land use change on soil quality degradation through digital mapping of soil quality indices and soil loss rate. Geoderma 2018, 318, 16-28. [CrossRef]

34. Zeraatpisheh, M.; Bakhshandeh, E.; Hosseini, M.; Alavi, S.M. Assessing the effects of deforestation and intensive agriculture on the soil quality through digital soil mapping. Geoderma 2020, 363, 114139. [CrossRef]

35. Soil Survey Staff. Keys to Soil Taxonomy, 12th ed.; USDA-Natural Resources Conservation Service: Washington, DC, USA, 2014.

36. Gee, G.; Bauder, J. Particle size analysis by hydrometer: A simplified method for routine textural analysis and a sensitivity test of measurement parameters. Soil Sci. Soc. Am. J. 1979, 43, 1004-1007. [CrossRef]

37. Walkley, A.; Black, I.A. An examination of digestion method for determining soil organic matter and a proposed modification of the chromic acid titration. Soil Sci. 1934, 37, 29-38. [CrossRef]

38. Richard, H.L.; Suarez, D.L. Carbonates and gypsum. In Methods of Soil Analysis, Part 3. Chemical Methods; Spark, D.L., Page, A.L., Helmke, P.A., Loeppert, R.H., Soltanpour, P.N., Tabatabai, M.A., Johnston, C.T., Sumner, M.E., Eds.; ASA/SSSA: Madison, WI, USA, 1996; pp. 437-474.

39. Yeomans, J.C.; Bremner, J.M. Carbon and nitrogen analysis of soils by automated combustion techniques. Commun. Soil Sci. Plant Anal. 1991, 22, 843-850. [CrossRef]

40. Carter, M.R.; Gregorich, E.G. Soil Sampling and Methods of Analysis; CRC Press: Boca Raton, FL, USA, 2007.

41. Dearing, J.A.; Dann, R.; Hay, K.; Lees, J.; Loveland, P.; Maher, B.A.; O'grady, K. Frequency-dependent susceptibility measurements of environmental materials. Geophys. J. Int. 1996, 124, 228-240. [CrossRef]

42. Walling, D.; He, Q.; Appleby, P. Conversion models for use in soil-erosion, soil-redistribution and sedimentation investigations. In Handbook for the Assessment of Soil Erosion and Sedimentation Using Environmental Radionuclides; Springer: Dordrecht, The Netherlands, 2002; pp. 111-164.

43. Swan ARH, S.M. Introduction to Geological Data Analysis, Blackwell Science; University of Portsmouth: Oxford, UK, 1995.

44. Peters, J.; De Baets, B.; Verhoest, N.E.; Samson, R.; Degroeve, S.; De Becker, P.; Huybrechts, W. Random forests as a tool for ecohydrological distribution modelling. Ecol. Model. 2007, 207, 304-318. [CrossRef]

45. Zeraatpisheh, M.; Ayoubi, S.; Jafari, A.; Tajik, S.; Finke, P. Digital mapping of soil properties using multiple machine learning in a semi-arid region, central Iran. Geoderma 2019, 338, 445-452. [CrossRef]

46. Team, R.C. R: A Language and Environment for Statistical Computing; R Foundation for Statistical Computing: Vienna, Austria, 2013.

47. Ayoubi, S.; Ahmadi, M.; Abdi, M.R.; Afshar, F.A. Relationships of 137Cs inventory with magnetic measures of calcareous soils of hilly region in Iran. J. Environ. Radioact. 2012, 112, 45-51. [CrossRef]

48. Khormali, F.; Ajami, M.; Ayoubi, S.; Srinivasarao, C.; Wani, S. Role of deforestation and hillslope position on soil quality attributes of loess-derived soils in Golestan province, Iran. Agric. Ecosyst. Environ. 2009, 134, 178-189. [CrossRef]

49. Paz-Gonzalez, A.; Vieira, S.; Castro, M.T.T. The effect of cultivation on the spatial variability of selected properties of an umbric horizon. Geoderma 2000, 97, 273-292. [CrossRef]

50. López-Granados, F.; Jurado-Expósito, M.; Atenciano, S.; García-Ferrer, A.; de la Orden, M.S.; García-Torres, L. Spatial variability of agricultural soil parameters in southern Spain. Plant Soil 2002, 246, 97-105. [CrossRef]

51. Wilding, L. Spatial variability: Its documentation, accomodation and implication to soil surveys. In Proceedings of the Soil Spatial Variability, Las Vegas, NV, USA, 30 November-1 December 1984; pp. 166-194.

52. Zolfaghari, Z.; Ayoubi, S.; Mosaddeghi, M.R. Spatial variability of some soil shrinkage indices in hilly calcareous region of western Iran. Soil Tillage Res. 2015, 150, 180-191. [CrossRef]

53. Seibert, J.; Stendahl, J.; Sørensen, R. Topographical influences on soil properties in boreal forests. Geoderma 2007, 141, 139-148. [CrossRef]

54. Solon, J.; Degórski, M.; Roo-Zielińska, E. Vegetation response to a topographical-soil gradient. Catena 2007, 71, 309-320. [CrossRef]

55. Norouzi, M.; Ayoubi, S.; Jalalian, A.; Khademi, H.; Dehghani, A. Predicting rainfed wheat quality and quantity by artificial neural network using terrain and soil characteristics. Acta Agric. Scand. Sect. B Soil Plant Sci. 2010, 60, 341-352. [CrossRef] 
56. Rodrigo-Comino, J.; Keshavarzi, A.; Zeraatpisheh, M.; Gyasi-Agyei, Y.; Cerdà, A. Determining the best ISUM (Improved stock unearthing Method) sampling point number to model long-term soil transport and micro-topographical changes in vineyards. Comput. Electron. Agric. 2019, 159, 147-156. [CrossRef]

57. Burst, M.; Chauchard, S.; Dambrine, E.; Dupouey, J.-L.; Amiaud, B. Distribution of soil properties along forest-grassland interfaces: Influence of permanent environmental factors or land-use after-effects? Agric. Ecosyst. Environ. 2020, 289, 106739. [CrossRef]

58. Karchegani, P.M.; Ayoubi, S.; Mosaddeghi, M.R.; Honarjoo, N. Soil organic carbon pools in particle-size fractions as affected by slope gradient and land use change in hilly regions, western Iran. J. Mt. Sci. 2012, 9, 87-95. [CrossRef]

59. Pedrol, N.; Souza-Alonso, P.; Puig, C.G.; González, L.; Covelo, E.F.; Asensio, V.; Forján, R.; Andrade, L. Improving soil fertility to support grass-legume revegetation on lignite mine spoils. Commun. Soil Sci. Plant Anal. 2014, 45, 1565-1582. [CrossRef]

60. Shrestha, R.K.; Lal, R. Carbon and nitrogen pools in reclaimed land under forest and pasture ecosystems in Ohio, USA. Geoderma 2010, 157, 196-205. [CrossRef]

61. Zhou, W.; Yang, K.; Bai, Z.; Cheng, H.; Liu, F. The development of topsoil properties under different reclaimed land uses in the Pingshuo opencast coalmine of Loess Plateau of China. Ecol. Eng. 2017, 100, 237-245. [CrossRef]

62. Yuan, Y.; Zhao, Z.; Niu, S.; Li, X.; Wang, Y.; Bai, Z. Reclamation promotes the succession of the soil and vegetation in opencast coal mine: A case study from Robinia pseudoacacia reclaimed forests, Pingshuo mine, China. Catena 2018, 165, 72-79. [CrossRef]

63. Li, B.; Tang, H.; Wu, L.; Li, Q.; Zhou, C. Relationships between the soil organic carbon density of surface soils and the influencing factors in differing land uses in Inner Mongolia. Environ. Earth Sci. 2012, 65, 195-202. [CrossRef]

64. Mohammed, S.; Hassan, E.; Abdo, H.G.; Szabo, S.; Mokhtar, A.; Alsafadi, K.; Al-Khouri, I.; Rodrigo-Comino, J. Impacts of rainstorms on soil erosion and organic matter for different cover crop systems in the western coast agricultural region of Syria. Soil Use Manag. 2021, 37, 196-213. [CrossRef]

65. Kizilkaya, R.; Dengiz, O. Variation of land use and land cover effects on some soil physico-chemical characteristics and soil enzyme activity. Zemdirb.-Agric. 2010, 97, 15-24.

66. Shahriari, A.; Khormali, F.; Kehl, M.; Ayoubi, S.; Welp, G. Effect of a long-term cultivation and crop rotations on organic carbon in loess derived soils of Golestan Province, Northern Iran. Int. J. Plant Prod. 2011, 5, 147-151.

67. Bakhshandeh, E.; Hossieni, M.; Zeraatpisheh, M.; Francaviglia, R. Land use change effects on soil quality and biological fertility: A case study in northern Iran. Eur. J. Soil Biol. 2019, 95, 103119. [CrossRef]

68. Zeraatpisheh, M.; Ayoubi, S.; Mirbagheri, Z.; Mosaddeghi, M.R.; Xu, M. Spatial prediction of soil aggregate stability and soil organic carbon in aggregate fractions using machine learning algorithms and environmental variables. Geoderma Reg. 2021, 27, e00440. [CrossRef]

69. Gol, C.; Dengiz, O. Effect of modifying land cover and long-term agricultural practices on the soil characteristics in native forest-land. J. Environ. Biol. 2008, 29, 667-682.

70. Karimi, A.; Haghnia, G.H.; Ayoubi, S.; Safari, T. Impacts of geology and land use on magnetic susceptibility and selected heavy metals in surface soils of Mashhad plain, northeastern Iran. J. Appl. Geophys. 2017, 138, 127-134. [CrossRef]

71. Ng, S.L.; Chan, L.S.; Lam, K.C.; Chan, W.K. Heavy metal contents and magnetic properties of playground dust in Hong Kong Environ. Monit. Assess. 2003, 89, 221-232. [CrossRef] [PubMed]

72. Rijal, M.L.; Porsch, K.; Appel, E.; Kappler, A. Magnetic signature of hydrocarbon-contaminated soils and sediments at the former oil field Hänigsen, Germany. Studia Geophys. Geod. 2012, 56, 889-908. [CrossRef]

73. Ayoubi, S.; Samadi, M.J.; Khademi, H.; Shirvani, M.; Gyasi-Agyei, Y. Using magnetic susceptibility for predicting hydrocarbon pollution levels in a petroleum refinery compound in Isfahan Province, Iran. J. Appl. Geophys. 2020, 172, 103906. [CrossRef]

74. Ayoubi, S.; Abazari, P.; Zeraatpisheh, M. Soil great groups discrimination using magnetic susceptibility technique in a semi-arid region, central Iran. Arab. J. Geosci. 2018, 11, 616. [CrossRef]

75. Hu, X.-F.; Su, Y.; Ye, R.; Li, X.-Q.; Zhang, G.-L. Magnetic properties of the urban soils in Shanghai and their environmental implications. Catena 2007, 70, 428-436. [CrossRef]

76. Royall, D. Use of mineral magnetic measurements to investigate soil erosion and sediment delivery in a small agricultural catchment in limestone terrain. Catena 2001, 46, 15-34. [CrossRef]

77. MULLINS, C.E. Magnetic susceptibility of the soil and its significance in soil science-A review. J. Soil Sci. 1977, $28,223-246$. [CrossRef]

78. Theocharopoulos, S.; Florou, H.; Walling, D.; Kalantzakos, H.; Christou, M.; Tountas, P.; Nikolaou, T. Soil erosion and deposition rates in a cultivated catchment area in central Greece, estimated using the 137Cs technique. Soil Tillage Res. 2003, 69, 153-162. [CrossRef]

79. Sac, M.; Uğur, A.; Yener, G.; Özden, B. Estimates of soil erosion using cesium-137 tracer models. Environ. Monit. Assess. 2008, 136, 461-467. [CrossRef] [PubMed]

80. Karchegani, P.M.; Ayoubi, S.; Lu, S.G.; Honarju, N. Use of magnetic measures to assess soil redistribution following deforestation in hilly region. J. Appl. Geophys. 2011, 75, 227-236. [CrossRef]

81. Khormali, F.; Ajami, M. Pedogenetic investigation of soil degradation on a deforested loess hillslope of Golestan Province, Northern Iran. Geoderma 2011, 167, 274-283. [CrossRef]

82. Fujiyoshi, R.; Sawamura, S. Mesoscale variability of vertical profiles of environmental radionuclides $(40 \mathrm{~K}, 226 \mathrm{Ra}, 210 \mathrm{~Pb}$ and 137Cs) in temperate forest soils in Germany. Sci. Total Environ. 2004, 320, 177-188. [CrossRef] 
83. Gaspar, L.; Quijano, L.; Lizaga, I.; Navas, A. Effects of land use on soil organic and inorganic C and N at 137Cs traced erosional and depositional sites in mountain agroecosystems. Catena 2019, 181, 104058. [CrossRef]

84. Liu, L.; Zhang, K.; Zhang, Z.; Qiu, Q. Identifying soil redistribution patterns by magnetic susceptibility on the black soil farmland in Northeast China. Catena 2015, 129, 103-111. [CrossRef]

85. Taghizadeh-Mehrjardi, R.; Nabiollahi, K.; Kerry, R. Digital mapping of soil organic carbon at multiple depths using different data mining techniques in Baneh region, Iran. Geoderma 2016, 266, 98-110. [CrossRef]

86. Zeraatpisheh, M.; Jafari, A.; Bodaghabadi, M.B.; Ayoubi, S.; Taghizadeh-Mehrjardi, R.; Toomanian, N.; Kerry, R.; Xu, M. Conventional and digital soil mapping in Iran: Past, present, and future. Catena 2020, 188, 104424. [CrossRef]

87. Mohammed, S.; Al-Ebraheem, A.; Holb, I.J.; Alsafadi, K.; Dikkeh, M.; Pham, Q.B.; Linh, N.T.T.; Szabo, S. Soil management effects on soil water erosion and runoff in central Syria-A comparative evaluation of general linear model and random forest regression. Water 2020, 12, 2529. [CrossRef] 